
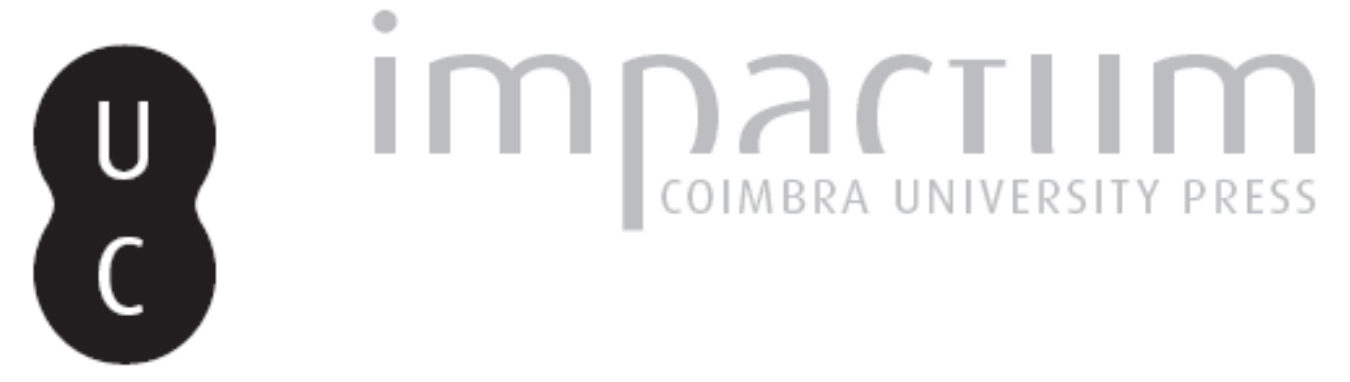

A aurora e o crepúsculo: a recepção de Bug-jargal e a questão racial no Brasil

Autor(es): $\quad$ Ribeiro, Maria Aparecida

Publicado por: Faculdade de Letras da Universidade de Coimbra

URL persistente:

URI:http://hdl.handle.net/10316.2/38980

DOI:

DOI:http://dx.doi.org/10.14195/0870-4112_1_5

Accessed : $\quad$ 26-Apr-2023 11:14:52

A navegação consulta e descarregamento dos títulos inseridos nas Bibliotecas Digitais UC Digitalis, UC Pombalina e UC Impactum, pressupõem a aceitação plena e sem reservas dos Termos e Condições de Uso destas Bibliotecas Digitais, disponíveis em https://digitalis.uc.pt/pt-pt/termos.

Conforme exposto nos referidos Termos e Condições de Uso, o descarregamento de títulos de acesso restrito requer uma licença válida de autorização devendo o utilizador aceder ao(s) documento(s) a partir de um endereço de IP da instituição detentora da supramencionada licença.

Ao utilizador é apenas permitido o descarregamento para uso pessoal, pelo que o emprego do(s) título(s) descarregado(s) para outro fim, designadamente comercial, carece de autorização do respetivo autor ou editor da obra.

Na medida em que todas as obras da UC Digitalis se encontram protegidas pelo Código do Direito de Autor e Direitos Conexos e demais legislação aplicável, toda a cópia, parcial ou total, deste documento, nos casos em que é legalmente admitida, deverá conter ou fazer-se acompanhar por este aviso. 


\section{Culturas em Diálogo}

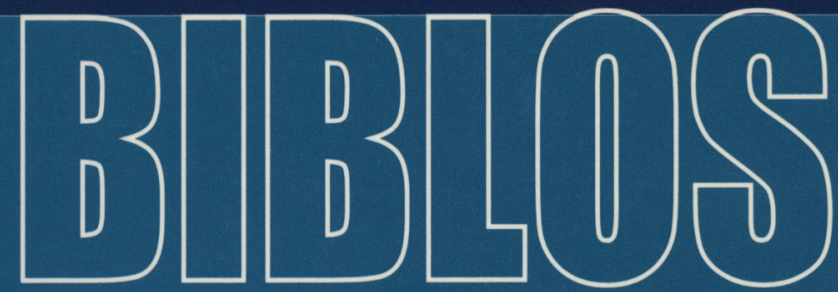


Maria Aparecida Ribeiro

Universidade de Coimbra

\author{
A Aurora e o Crepúsculo: a Recepção de Bug-jargal \\ e a Questão Racial no Brasil
}

Abstract:

Bug Jargal, the novel by Victor Hugo, has been well accepted in Brazil and Portugal. Focusing particularly on episodes such as that of the fire, that of the rebels' parade or that of the words of the song in which a Negro declares himself king and slave at the same time, Gonçalves Dias, José de Alencar, Gomes de Amorim, Carlos Gomes and Gama Malcher highlight and situate these scenes in new contexts, thus giving them new meanings. 1

\section{UM CASO DE RECEPÇÃO?}

Em meio ao clarão do incêndio que devasta o solar de D. António de Mariz, o vulto de Peri aperta Cecília adormecida nos braços, deixando após si uma cena de tumulto e dor: as chamas devoram a figura "horrível e medonha de Loredano" que se ergue como um espectro no meio das labaredas; o vulto de D. António de Mariz, de pé, no meio de seu gabinete, empunha na mão esquerda a imagem de Cristo e, na direita, a espingarda; abraçada aos seus joelhos, D. Lauriana; Aires Gomes e os outros aventureiros imóveis e ajoelhados a seus pés; sobre um monte de ruínas, figuras sinistras de aimorés, "semelhantes a espíritos diabólicos dançando nas chamas infernais" (Alencar, 1994b: 293). Todas essas cenas ficaram, certamente, na memória do leitor de $O$ Guarani, juntamente com aquela que encerra o romance e que vem, mais uma vez, reiterar o heroísmo do índio, enquanto sugere a fundação do Brasil: sobre uma palmeira, sempre com Cecília, tentando vencer o dilúvio e revivendo a lenda de Tamandaré, ele diz à moça "quase inanimada": — “Tu viverás!" (Alencar, 1994b: 317). 
Quem lê Simá, de Lourenço da Silva Araújo e Amazonas, publicada em 1857, no mesmo ano de $O$ Guarani, depara-se com solução semelhante, embora escrita com menor pendor dramático: uma revolta de índios contra brancos, um incêndio, um tecto em chamas que desaba, pilhas de cadáveres.

Poderá ser mera coincidência, procedimento típico de índios, mas a verdade é que não deixa de ser intrigante que um outro texto, agora um drama, e de autor português, mas tendo por cenário a Amazónia, onde ele viveu parte da infância e adolescência, apresente um pai a exclamar horrorizado que viu abater-se o tecto quando ia salvar a filha das chamas postas em sua casa pelos escravos revoltados, e que, logo depois, veja surgir do fogo o bom escravo negro com a moça desmaiada em seus braços. Seria um dos casos de recepção de que nos fala Grimm (1977) ou apenas mera coincidência? Posta em cena em 1854, no Teatro de D. Maria II, antes, portanto, de $O$ Guarani vir a público, essa peça, Ódio de Raça, da autoria de Gomes de Amorim, mostra um herói escravo, que ama em silêncio a moça branca e, em silêncio, lhe diz, como Peri, "Tu viverás!". Mas nem Alencar nem Lourenço Amazonas saíram do Brasil, e o drama foi publicado apenas em 1869. Teria $O$ Guarani servido de paradigma a Amorim e Amazonas ou haveria um quarto texto subjacente aos romances brasileiros e à peça portuguesa?

Para os frequentadores do Romantismo brasileiro, uma tradução de Gonçalves Dias e outra de Castro Alves, poderão funcionar como pista, assim como os aficcionados da história da ópera, encontrarão no Pará, em 1890, um caminho ou outra situação intrigante, enquanto os leitores do Romantismo francês, terão em Victor Hugo um porto seguro para suas indagações. É que a cena do incêndio e da salvação da moça branca está em Bug-Jargal, cuja canção do protagonista foi traduzida pelo poeta baiano, grande leitor de Hugo, reverenciado em várias epígrafes de seus poemas, assim como pelo autor da "Canção do Exílio", que também se revela um seu leitor desde o primeiro livro, voltando a aparecer na ópera do paraense Gama Malcher, homónima do romance francês. Se isso dá a dimensão, ainda que pequena, da recepção do romance de Victor Hugo $^{1}$ no Brasil e em Portugal ${ }^{12}$, leva também a indagar sobre a função e os efeitos desses recortes nos novos contextos.

\footnotetext{
1 A esse respeito ver interessante artigo de Sergio Paulo Rouanet, "A Revolução Francesa das Letras", Folha de S. Paulo, 14/7/2002.

2 Como já tivemos ocasião de anotar num outro estudo (Ribeiro, 1999), a canção de Bug-Jargal tem passado despercebida aos estudiosos das literaturas africanas de língua
} 


\section{O TEXTO DE HUGO}

Nascido, segundo sua filha, Adèle, em Hugo raconté par une témoin de sa vie, de uma brincadeira de adolescentes, o romance Bug-Jargal teve duas versões que diferem ideologicamente: a primeira, escrita em 1818, quando o seu autor tinha dezesseis anos, e publicada em 1820; a segunda, em 1825-26 (cf. Laforgue, 1989: 1-2).

Reunindo factos que poderia ter ouvido narrar no seio da própria família (o avô materno do escritor teria sido negreiro, capitão de navio com viagens feitas à ilha; e seus ancestrais teriam propriedades em S. Domingos) como quer Toumson (1979); ou, como chama a atenção Jacques de Carina (1989), conhecimentos adquiridos no contexto da época em que viveu (sua mãe descendia da burguesia de Nantes, onde havia muitos negros, e onde conheceu pelo menos um proprietário em $\mathrm{S}$. Domingos; seu pai foi amigo do primeiro marido de Josefina, representante como a futura imperatriz, da velha aristocracia crioula da Martinica) Victor Hugo, segue o caminho de Picquenard (.Zqflora ou la bonne négresse, 1800), R. Périn (L’Incendie du Cap, 1802), Mlle Palaiseau ( $L$ 'Histoire de Mesdemoiselles de Saint-Janvier, les deux seles blanches sauvées du massacre de Saint-Domingue, 1812), Balzac (Le Nègre, 1821), Charles de Rémusat (L'Inssurrection de Saint-Domingue, 1824), Adèle Daminois (Lydie ou la créole, 1824) e de muitos outros autores que se inspiraram na revolta em que os escravos de São Domingos conquistaram para si e para seus descendentes a condição de homens livres e criaram um país independente, o Haiti, a primeira república, depois dos Estados Unidos, a libertar-se da tutela colonial. O próprio pai de Hugo, cuja Mémoire sur les moyens de suppléer ci la traite des nègres par des individus libres et d'une manière epa garantisse pour l'avenir la sûreté des colons et la dépendance des colonies foi publicada no mesmo ano em que ele escreveu Bug-Jargal, inspirou-se nesses factos históricos (cf. Cauna, 1989). Aliás, por essa época, a Académie Française mostra a actualidade e o interesse do assunto, propondo, em 1816, a abolição do tráfico negreiro, como tema do seu concurso de poesia e, em 1826, a emancipação do Haiti.

\footnotetext{
portuguesa. Sua temática - amor do negro pela branca, - foi glosada, entre outros, por Costa Alegre, nomeadamende no poema "?", cujo excipit é "Porém brilhante e pura./ Talvez seja a manha/ Irmã da noite escura!/ Serás tu minha irmã? (Alegre. 1994: 67)
} 
É nesse horizonte que surgem as duas versões de Bug-Jargal, romance onde, na segunda delas, o capitão Leopold d'Auverney (Delmar, em 1820) narra sua história aos companheiros de acampamento, durante as guerras da Revolução (De acordo, aliás, com o Prefácio da $2^{\text {a }}$ versão, Hugo diz que este romance é "um fragmento de uma obra mais extensa que devia ser composta com o título Contes sons la Tente"). Nascido em França e sobrinho de um rico proprietário em São Domingos, d'Auverney com ele vivia desde muito jovem, tendo como prometida Maria, sua prima, anjo de candura e de inocência, que costumava, em seus passeios pela propriedade, frequentar um aprazível pavilhão nas margens de um regato, sempre adornado por seu noivo com "as mais belas flores que podia colher". Num desses passeios, porém, Maria encontra as flores esmagadas e, no lugar delas, um ramo de malmequeres. A cena se repete e uma voz lhe canta um romance espanhol de alguém que se declara negro e pergunta "Porque foges de mim, Maria?", afirmando que "o dia tem necessidade de se unir com a noite para produzir a aurora e o pôr-do-sol, que são mais belos do que ele" (Hugo, s.d.:340). Este homem é Pierrot, um escravo de gigantescas proporções e de nobre porte, que vai mostrando sua coragem, sabedoria, dedicação e altivez a cada momento: primeiro salva Maria de ser devorada por um jacaré; depois, oferece-se para ser castigado no lugar de outro negro que ia ser chicoteado injustamente; mais tarde livra a moça das mãos dos negros revoltados e das chamas do incêndio do Forte Gallifet e mantém-na, com a ama, a salvo num esconderijo; finalmente, liberta o próprio d'Auverney, leva-o ao encontro de Maria, e livra-o por mais duas vezes da morte. Filho de um rei do Cacongo, que "administrava justiça na soleira da sua porta", Bug ordena a seus companheiros de luta, que soltem Leopoldo: "- Ele viverá!" (Hugo, s.d.:435). Sua última façanha é entregar-se aos brancos para morrer no lugar de dez negros seus companheiros.

A tradição do negro escravo, ao mesmo tempo revoltado e generoso, vem em auxílio de Hugo para criar o super-herói Pierrô/BugJargaP: ele existia em Orooko ou le Prince Nègre, de Mrs. Behn, em Le Blanc et le No ir, de Pigault-Lebrun, no anúncio do surgimento de um Spartacus negro feito por Raynal em sua célebre Histoire Philosophique, no Adonis ou le bon nègre, de Picquenard.

Outras personagens de existência histórica e suas acções são transportadas para o romance, como o célebre Caredeux, de Cul-Sac, que

3 A esse respeito v. G. Debien (1952) e L:F. Hofmann (1989)

Faculdade de Letras Universidade de Coimbra 
fez plantar as cabeças dos escravos insurrectos em duas alas, como palmeiras, nos dois lados da avenida de sua casa, e é transformado no Citoyen-Géneral C. que toma a mesma atitude. O episódio do carpinteiro que morre imprensado entre duas tábuas por ordem de Biassou, para que tenha um fim de acordo com a sua profissão, assim como a cronologia dos acontecimentos, o papel dos chefes, e o que diz respeito a Gallifet são pescados em Bryan Edwards. Garran-Coulon fornece várias ideias, além do episódio do plantio das cabeças dos revoltosos e de uma outra cena atroz: a morte do menino branco levado na ponta de uma lança como estandarte. O nome Pierrot (o nome de Bug como escravo) aparece como o de um dos chefes negros dos acontecimentos revolucionários do Cabo. assim com Boukmann e Biassou, também tomados como personagens do romance de Hugo, surgem em Zoflora.

Habibrah, o anão, que Jacques de Cauna sugere ter saído dos Contos Mil e Uma Noites e não de qualquer propriedade dominicana, e cuja origem Hugo atribui a um presente do governador da Jamaica ao tio de d'Auverney, aproveitando para comentar que este gostava do fausto português adquirido no tempo em que vivera no Brasil (aliás, esta é a primeira de duas "farpas" lançadas pelo escritor contra os portugueses), é odiado logo de início por Leopoldo. Revoltado com a sua aparência e porque entende os privilégios que lhe são concedidos por seu dono. satisfazendo-lhe os pedidos, fazendo-o dormir no seu próprio quarto e dando-lhe comidas da sua mesa, não passam de um tratamento de cão de luxo, de afrontas a um ser, afinal, humano, acaba por assassiná-lo durante a rebelião. Mulato, é mau com os outros escravos, que o temem como a um obi (embora, como justifica, para apressar a rebelião) e o oposto do generoso negro Pierrot/Bug-Jargal.

A flora exuberante e exótica que ajuda a compor o cenário é recortada sobretudo de Voyage d'nn natur aliste, da autoria de Descourtilz, assim como o pavilhão onde Maria costumava refugiar-se é importado de Paulo e Virgínia. E o célebre incêndio, que atravessou o Atlântico e fez escola no Brasil? Esse vem das Soirees Bennuclinnes ou Entretiens sur les évenements qui ont opéré la mine de Saint-Doniingue, de Bordelais Félix Carteaux.

Entre as duas versões de Bug-Jargal, não existem diferenças na intriga e os acréscimos não modificam o conjunto da trama, mas ocorrem mudanças de ordem ideológica, como bem mostrou Pierre Laforgue (1989): na edição de 1820, a narração tem lugar quinze anos depois da revolta dos escravos, enquanto na segunda versão a diferença é de apenas dois anos e há um convite ao leitor para examinar os factos à luz de 93. 
Se, na novela, os colonos escravagistas são regalistas, no romance, embora continuando partidários da escravatura e terrivelmente racistas, eles passam a ser republicanos; já os negros, revolucionários na primeira versão, mostram uma total confusão simbólica, na segunda, e contradizem na prática suas posições ideológicas.

Em seu texto Hugo mostra o ódio entre raças: os brancos menosprezam os negros e mulatos, que escravizam (haja vista a atitude do tio de Leopoldo que chicoteia um negro porque lhe destruiu uma roseira e que trata Habibrah como animal de estimação) e até mesmo os colonos que são sang inelés (observe-se o episódio em que Leopoldo considera uma ousadia um sang melé dançar com sua noiva); os negros e mulatos odeiam os brancos pelas humilhações sofridas; por sua vez os mulatos são desprezados pelos negros (confrontado com a perfídia de Biassou. BugJargal, observa: "Bem mostra que não é um negro, mas sim um mulato1", Hugo, s.d.: 425).

Se essa é uma fala ditada pelo racismo, haverá outros comportamentos que o revelam de maneira mais subtil. Não será somente pelo comportamento exemplar de Bug-Jargal (que nem chega a ser totalmente silencioso em seu amor por Maria), nem apenas pela proclamada inocência da moça branca, que - caridosa e reconhecida ao escravo por lhe ter salvo a vida — não percebe essa paixão, que até lhe "parece impossível". Aliás, ela chega mesmo a explicitar que a humildade devia ser inerente ao comportamento de um escravo (cf. Hugo, s.d.: 420). Se o tio de Leopoldo era um déspota, é a Habibrah que o sobrinho, penalizado (apenas penalizado) com o sofrimento dos escravos, incrimina por não interceder por seus companheiros. Mais: é com termos pejorativos que Leopoldo d'Auverney fala da língua, das crenças e de outros hábitos dos escravos e caracteriza os revoltosos. Estes são bandos de negros, hordas de negros, formigueiros, nuvem de insectos; o crioulo, é um jargão, um jargão ininteligível; suas práticas, "costumes bizarros"; eles temem o Habibrah anão - um obi - e acreditam nas pantomimas de Habibrah feiticeiro.

Em meio aos horrores praticados pelos negros revoltosos e mulatos (vejam-se Biassou, Rigaud e Habibrah) contra os brancos (que ocupam bastante mais tempo da narrativa que os praticados pelos brancos contra os negros) a figura de Bug-Jargal (que acaba por dizer a Biassou "os brancos são menos cruéis que nós") é uma excepção. Ele nada faz contra os brancos: as atrocidades praticadas não são de sua autoria; como ele afirma a Leopoldo, "não fui eu, foram os meus" (Hugo, s.d.: 411). A sua própria liderança lhe foi conferida pelos escravos insurrectos que 


\section{A RECEPÇÃO DE BUG-JARGAL}

também lhe outorgaram a chefia dos do Cerro Vermelho, ao verem que um senhor lhe matava os filhos. Aliás, Bug-Jargal não está na luta por ter sido vendido "a diferentes senhores como uma peça de gado1", mas porque sua mulher, prostituída entre os brancos e separada dos filhos, lhe pediu vingança. A própria condição escrava a que foi submetido merece uma causa, que não a lei do mais forte, mas a expiação do pecado de ambição e luxúria de seu pai que, rei do Kakongo, de lá viera, seguindo um capitão espanhol que the prometera mais terras e mulheres brancas.

Confrontando essa atitude de Jargal, que nada tem de revolucionária, com as palavras de Biassou ao grupo que lidera e a explicação de Habibrah a Leopoldo, pode-se observar, como muito bem explica Hoffmann (1989), um paradoxo ideológico no romance. Biassou lembra aos seus homens que os brancos - ricos, poderosos, bem vestidos, armados e com casas magníficas - desprezam os escravos "por serem negros e nus"; que a paciência de nada lhes valeu naquele espaço de opressão; que os direitos só podem ser conquistados pela força e que o exemplo de São Domingos será seguido pelos escravos de Cuba e da Jamaica. Habibrah não se quer vingar de maus-tratos, mas de humilhações, de haver sido forçado a desempenhar um papel, e afirma a d'Auverney que este só lhe conhece a máscara; não o verdadeiro rosto. Com isso, deduz Hoffmann, Hugo tenta chamar a atenção para o facto de que só em liberdade pode o homem ser ele mesmo. Ou dito de outra maneira mais elementar: colocando em cena o despotismo do colono contra nobres, como Bug-Jargal, ou cruéis, como o anão e Biassou, o escritor tenta, em última análise, mostrar a injustiça da escravatura. ${ }^{3}$

\section{DE NEGRO A ÍNDIO}

Antes de ser traduzida no último quartel do século $\mathrm{XX}$ por Castro Alves, a canção posta por Victor Hugo na boca de Bug Jargal recebeu também uma versão para o português de Gonçalves Dias, que a incluiu nos Últimos Cantos (1851). Leitor do poeta francês, o brasileiro já havia tomado versos seus por epígrafe em "O Vate" e em vários momentos de "O Soldado Espanhol", poemas incluídos nos Primeiros Cantos (1846). Essa seria uma pista para que se pudesse ler a sua "Canção do índio", também pertencente aos Primeiros Cantos, como uma reescrita da canção do herói negro de Hugo. Por outro lado, o tema da escravidão era caro ao poeta brasileiro e a condição de inferioridade pela cor da pele não era sua desconhecida: não se pode esquecer que nas suas 
origens estavam tanto o índio como possivelmente também o negro, e que foi provavelmente o facto de ser mestiço a causa de lhe ter sido recusada a mão da mulher que amava. Ou, pelo menos, assim o entendeu Gonçalves Dias. Numa espécie de resposta à negativa de seu pedido de casamento com Ana Amélia Ferreira do Vale e, ao mesmo tempo, numa glosa à sugestão de união de raças existente nos versos "junto ao dia / A noite o poente cria / E cria a aurora também, / Que mais luzentes belezas, / Mais doces que ambos tem.", que ele traduzira do romance de Victor Hugo (Dias, 1959: 454), escreveu "Tu não queres ligar-te comigo", poema no qual pergunta: "E tua casa no sangue tão clara, / Que eu me honrasse de unir-me contigo." (Dias, 1959: 625).

Some-se a isso, a hipótese de que Dias - cujo medievismo, bebido em Coimbra entre os de $O$ Trovador, produziu uma espécie de alba indígena, o célebre "Leito de folhas verdes" - pode ter encontrado na humildade de Bug Jargal (socialmente escravo, mas querendo ser também escravo por amor) uma forma de vassalagem, e, assim, transposta a canção do negro para a boca de um selvagem, também deslumbrado diante da mulher branca que se banha ${ }^{4}$, uma vez que o paradigma da diferença de classes, olhado pelo prisma do Brasil, podia ser identificado com a diferença de raças, que, aliás, existia entre colonizador e colonizado. Assim é que o ódio de raças, presente no romance de Hugo (e na própria canção de Bug Jargal — "Té a vingança m'esquece"5), e que aflora em vários poemas indianistas de Gonçalves Dias, cantor do índio vítima, da "extinta raça", também aparece no "odeio tanto os teus, como te adoro", no "vencer por teu amor meu ódio antigo", deste "Canto do índio" (Dias, 1959: 110).

\section{A(S) PEÇA(S) DE AMORIM}

Tendo vivido na Amazónia, onde foi parar vendido por um daqueles engajadores que tanta gente arrastaram para o Brasil no século XIX, Francisco Gomes de Amorim (A-Ver-o-Mar, 13/8/1827 - Lisboa, 4/11/1891), viveu, dos dez aos dezoito anos, uma experiência que certamente o distingue entre os escritores portugueses, que pontua a sua peça mais célebre — Fígados de Tigre (1857) «paródia de melodramas»,

\footnotetext{
4 É de lembrar que Ferdinand Denis já havia composto o seu Les Maxakalis. onde o índio é tomado de amores pela mulher branca.

5 Usamos aqui a própria tradução de G. Dias (1959:453).
} 
e marca, de forma notável, um seu romance (Os Selvagens, 1875) e dois outros dos seus dramas (o já mencionado Ódio de Raça, escrito em 1854 e representado no mesmo ano, no Teatro de D. Maria II, e $O$ Cedro Vermelho, levado à cena em 1856 também no D. Maria).

Passado no Pará de 1846, Ódio de Raça deve sua origem, segundo o próprio autor, a uma sugestão de Almeida Garrett, a quem Amorim narrara a vida dos negros no Brasil, depois de o ouvir ler um projecto de lei, da autoria do Marquês de Sá da Bandeira, para extinguir a escravidão dos domínios portugueses. A ideia era "pôr em relevo os horrores da escravidão" e auxiliar "o público a formar um juízo com que desse força aos intuitos legisladores" (Amorim, 2000: 7).

Ao ser publicada, em 1869, a peça, ganhou como epígrafe palavras de Ferdinand Denis, extraídas do livro Brèsil e para as quais já se teve oportunidade de chamar a atenção noutro trabalho (Ribeiro, 1998): "Ici [no Brasil], comine en hien d'antres endro its, une question de race devint une question de haine." (Amorim, 1869: 4). Denis ${ }^{6}$, buscando o testemunho de Debret, que polariza a rivalidade entre "o orgulho americano do mulato" e o "brio português do brasileiro branco" (Denis, 1980:158), comenta o facto de os europeus exigirem uma pureza de origem, mas, ao mesmo tempo, irem ajudando a aumentar o número de mulatos.

Gomes de Amorim apresenta em seu texto, pós-coloniaf ao contrário de Hugo, não só o latifúndio e a escravatura (heranças da colónia), mas também os novos dados que a extinção do tráfico negreiro (embora o Brasil dela fizesse letra morta) ${ }^{7}$ introduzira: a imigração e o trabalho assalariado, em função dos quais ele próprio fora levado ao Pará.

\footnotetext{
6 Nesse ponto G. de A. emparelha com os brasileiros. Vejam-se as palavras de Macedo: "Citar o nome de M. Ferdinand Denis é citar uma autoridade" (Macedo. J. M. \& outros, 1851: 443). Diga-se também que a miscigenação racial era algo que horrorizava os franceses. O Conde de Gobineau, cônsul da França no Rio de Janeiro e amigo de Pedro II. ao escrever A Diversidade Moral $\boldsymbol{e}$ Intelectual das Raças (1856), previa a extinção do povo brasileiro, dentro de duzentos anos, em função da mistura racial. Agassiz, leitura que Amorim cita em suas notas, também fala da deterioração decorrenta do amálgama de raças e vê no Brasil, mais que em qualquer outro lugar, a miscigenação produzindo um tipo "indefinido, híbrido, deficiente em energia física e mental".

7 A Inglaterra fazia uma campanha abolicionista entre os restantes países do mundo, pois, como abolira em 1807 o tráfico e, em 1833, o trabalho escravo nas Antilhas, precisava concorrer no mercado açucareiro em pé de igualdade com os outros países e não lhe interessava que estes utilizadores da mão-de-obra escrava pudessem ter uma produção
} 
Roberto, viúvo, senhor de uma fazenda, tem uma filha, Emilia, a quem idolatra. Em sua casa e no seu armazém, trabalham Manuel, seu sobrinho, recém-chegado de Portugal, que serve como caixeiro e que acaba por apaixonar-se pela prima; o escravo Cazuza, preto Cabinda, que ama Emilia em silêncio; Domingos, escravo mulato, a quem Roberto, sem saber por quê, está sempre disposto a perdoar as faltas e que deseja Emilia; a tapuia Marta, índia aculturada, mãe de leite de Emilia e também de Domingos, cuja mãe, a escrava Maria, faleceu.

Por ter roubado dinheiro e imputado a culpa a Cazuza, Domingos é açoitado por ordem de Emilia. Depois disso, foge, mas planeja voltar e vingar-se. Armado de uma espingarda que Marta lhe forneceu a troco de cachaça, entra na sala onde Emilia dorme numa rede. Cazuza contempla-a e segura a rosa branca que a moça tinha nos cabelos e lhe dera ao sonhar com o primo. O mulato atira no negro, quando este defende Emilia, e foge. Pouco tempo depois, planeja nova investida. Sabendo pela tapuia que é filho de Roberto, enfrenta-o e diz a Emilia que quer tomá-la por mulher, ameaçando matar-lhe o pai se ela não consentir em acompanhá-lo. No entanto, mais uma vez, aparece Cazuza que a salva. Fica, porém ainda mais ferido, pois o mulato esfaqueia-o. Preso, Domingos é libertado pelos outros mulatos e põe fogo à casa, onde está Emilia. Manuel, porém, imaginando que ele ia assassinar Roberto, mata-o e corre a salvar a prima, mas Cazuza, movido pelo amor que o prende à moça, embora ainda não recuperado da ferida que o fizera perder muito sangue, disputa com ele o privilégio de salvar a sinhazinha ("Não. Não será um branco!", Amorim, 2000: 96) e tira-a desfalecida de entre as chamas, para morrer logo a seguir.

Aparecem, portanto, em Ódio de Raça: o brasileiro branco; o branco português recém-chegado, caixeiro; três escravos - um negro e dois mulatos; uma tapuia, isto é, uma índia aculturada, que trabalha na fazenda (possivelmente sob um regime de escravidão). Não será a divisão racial aliada à divisão de trabalho que irá corresponder ao antagonismo proposto no título: este irá desenvolver-se em torno do mulato que odeia o negro, tão escravo quanto ele, e o branco senhor. $\mathrm{O}$ ódio entre as raças advém da escravidão, "consagração legal de todos os erros, de todas as superstições, de todos os preconceitos, de todas as ignomínias e de todos

mais barata. No Brasil, a extinção oficial do tráfico data de 1831 . mas só em 1850 , com a
Lei Eusébio de Queirós é que foram adoptadas medidas rigorosas. Gomes de Amorim
regista essas infrações em $\boldsymbol{O}$ Cedro Vermelho, cuja acção se passa no ano de 1837. 
os crimes que gera a ignorância”, conforme Gomes de Amorim já aflora na introdução, citando Charles d'Expelly (Amorim, 2000: 11).

O negro, Pai Cazuza ou José, trabalhador e inteligente, odeia o mulato pelas regalias que este recebe de Roberto (motivadas por um afecto instintivo do branco com relação a Domingos, que afinal é seu filho, embora ambos o ignorem). Cazuza diz que "mulato não tem raça". E tão enquadrada no sistema escravocrata é a construção desta personagem que ela acaba por se valorizar a si própria como mercadoria, da mesma maneira que o faz o seu senhor: o seu orgulho em ser Cabinda vem da superioridade que os brancos dizem ter essa etnia sobre os outros negros, tornando mais caros os escravos a ela pertencentes. A alfa betização e o Cristianismo que a civilização lhe proporcionou não mudaram a condição de Cazuza; apenas foram usados para torná-la mais "suave", embora este aspecto apareça quase apagado no drama, porque o Cristianismo é visto como um bem, um freio: a religião não lhe revelou a igualdade dos homens; serviu apenas para que o negro sublimasse a sua paixão (por um momento consciente) pela sinhazinha. A sós com a filha do patrão, ele contempla-a, mas é incapaz de tocá-la (exactamente por lembrar-se de que é cristão e escravo). Seu único momento de prazer foi trazê-la nos braços para salvá-la do incêndio ("tê-la" para depois morrer), transformando-se no herói da peça - o primeiro herói negro do teatro romântico de língua portuguesa ${ }^{8}$. Completando este perfil, Gomes de Amorim associa à honestidade de Cazuza a coragem e a força (traço que não desenvolve). Embora de forma ténue o escravo tematiza uma ideia cara a Gomes de Amorim, fruto certamente de suas leituras de Chateaubriand $^{9}$ ' à qual dará maior relevo em Os Selvagens e no Remorso Vivo - o Cristianismo como instrumento de civilização.

Poderia parecer que o episódio do incêndio, com o negro trazendo a moça nos braços para entregá-la a seu enamorado, explorado no Bug-Jargal de Hugo, seria apenas uma coincidência de estratégias, se Manuel não fosse, como d'Auvernay, sobrinho do senhor e, como ele, amasse a prima. As flores colocadas por Bug-Jargal no pavilhão

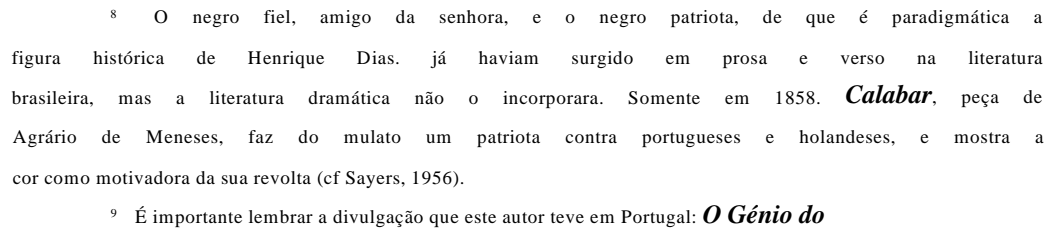

Cristianismo, por exemplo, foi traduzido por Filinto Elísio pouco depois de sua publicação. 
frequentado por Maria parecem ter sido substituídas pela rosa branca que Cazuza, também por duas vezes salvador de Emilia, guarda como fetiche. Mas a ideia de simples coincidência de cenas dissipa-se quando em O Cedro Vermelho e em Os Selvagens, encontramos outras cenas de Bug-Jargal, o que nos revela um Amorim leitor de Hugo.

N'O Cedro, onde o escritor repete o esquema amoroso em que entram brancos e não brancos ${ }^{10}$ e faz a heroína ser salva também duas vezes pelo apaixonado platónico, a cena recortada do Bug-Jargal é a do crocodilo que ia atacar Maria: Lourenço/Cedro Vermelho, o índio juruna, livra Matilde, a sinhazinha branca, de uma fêmea de jacaré. Já em $O s$ Selvagens, a cena transplantada do romance hugoano é aquela que descreve a diversidade de roupas e bandeiras dos revoltosos que desfilavam diante de Biassou. Hugo, vendo na "mistura o signo ou símbolo do mal” (Hoffmann, 1989: 2), utiliza maneiras pejorativas de descrever:

...eram negros absolutamente nus, munidos com maças, tomahawks e cassetetes, marchando ao som de galhos de bode, como os selvagens; outras vezes, eram batalhões de mulatos, equipados à espanhola ou à inglesa, bem armados, regulando os passos pelo toque dos tambores; depois, uma coorte de negras e rapazes carregados com forcados e espetos; fatras levando velhas espingardas sem cão e sem cano; griottes com os vestuários bordados; griots, fazendo caras assustadas e contorsões esquisitas, cantando árias incoerentes na viola, no tantã e no balafo. Esta singular procissão era cortada, de tempos em tempos, por destacamentos heterogéneos de griffes, marabutos, a sacatras, mamelucos e quarterões de sang-mêlés livres, ou por hordas nómadas de escravos fugitivos de atitude altiva, com carabinas brilhantes, arrastando nas suas fileiras as suas carretas carregadas, ou alguma peça de artilharia roubada aos brancos, que lhes servia mais de troféu do que de arma de defesa, e cantando hinos do Camp du Grand Pré e do Oua-Nassê. Acima de todas estas cabeças, flutuavam bandeiras de todas as cores, brancas, vermelhas, tricolores, flores-de-lis, encimadas com um barrete de liberdade e tendo inscrições como estas; Morte aos padres e aos aristocratas! - Viva a religião! - Liberdade! Igualdade! - Viva o rei! - Abaixo a metrópole! - Viva a Espanha! - Não mais tiranos! etc. Era uma confusão que indicava que todas as forças de rebeldes não eram mais do que

\footnotetext{
Uma sinhazinha brasileira (Matilde), um namorado português recém-chegado (agora um guarda-marinha), um apaixonado silencioso de raça não branca (dessa vez um índio juruna e liricamente correspondido, Lourenço/Cedro Vermelho), um homem mau também não branco (no caso, um índio mura, Brás).
} 
meios sem fim, e que neste exéreito mão havia menos desordem nas ideias que nos homens. (Hugo, s.d.: 403-404)

Amorim, apesar de ter lutado na Patuleia, usa as lentes das teorias raciais que viam a miscigenação como degeneração (cf. Ribeiro, 1998) aprecia a massa revoltosa, com o mesmo olhar pejorativo:

\footnotetext{
Alguns homens vinham vestidos de pano avermelhado, tinto em muruxi, aspiração embrionária dos comunistas vermelhos do tempo. Outros usavam fardas bordadas sobre a pele. Muitos traziam as camisas sem mangas as calças sem pernas. Os que não estavam inteiramente nus, vinham rotos, esfrangalhados, grotescos; lembravam bandos de macacos em trajos de carnaval, ou doidos desengaiolados, que tivessem saqueado os velhos guarda-roupas de dez teatros de província! Unicamente num ponto havia igualdade entre eles: andavam todos descalços.

As caras eram indescritíveis, estúpidas, ferozes, audaciosas, covardes, espantadas, humildes, idiotas, selvagens, insensatas, incríveis de imprevisto, estupendas de brutalidade! Vendo-se tão extraordinária acumulação de criaturas diferentes, tão injustificável promiscuidade de fisionomias, de colorido, de raças, em que até havia brancos mais sujos do que os próprios pretos poderia julgar-se que o diabo, desejoso de pôr o inferno em harmonia com os progressos da ciência e da higiene moderna, o lavara com as águas do Caiari. que despegaram de lá aquele amontoamento de imundícies hediondas, farrapos de pano e de carne, escória e lixo humano! (Amorim, [1982]: 158-159)11
}

Se o texto de Hugo é pós-revolucionário e pós-abolicionista, o que mostra a "má-fé” dessa descrição, como anota Hoffmann (1989:2), ainda que ela faça parte das lembranças que d'Auvernay guardou de quando esteve cativo de Biassou, o de Amorim antecede a abolição tanto no Brasil quanto em Portugal, e tem intenção de auxiliá-la. A Cazuza cabem os discursos anti-escravistas: o cativeiro dos pretos é uma "invenção dos brancos", mas ele acaba por exclamar "Liberdade, tu és uma mentira... até para os brancos" (Amorim, 1869: 40).

Essas palavras contemplam não propriamente os problemas da escravidão negra no Brasil, mas o facto de ser Portugal promotor dessa personagem Gavroche, de Os Miseráveis, sem que nos ocorresse o passo citado do BugJargal. 
monstruosidade que, na sua versão mais recente, a escravização de portugueses, atingiu o próprio Gomes de Amorim. Acicatando os liberais seus contemporâneos, "gente que fala muito em liberdade, e negoceia em escravatura", o dramaturgo faz Cazuza lembrar que esse comércio de carne humana encheu o Brasil de "portugueses vendidos e comprados por seus irmãos" (Amorim, 1869: 87). O discurso assume sempre um tom que apela ao sentimento, e não à razão do público (não fosse a peça romântica). Algumas denúncias que poderiam causar terror no público acabam por perder a força, devido à contextuaiização recebida. E o caso de o Governo brasileiro ter de obrigar a pedir licença para açoitar um escravo e limitar o número de açoites a ser dado, o que faz que o senhor peça sempre mais, e acabe aplicando o castigo que deseja. Posta na boca de Roberto, a observação não chega a enfatizar a hediondez dessa prática, porque diluída pelo efeito cómico do exagero.

No discurso de Cazuza, pode ainda ser notado o cuidado de Amorim em manter-se "amigo do Brasil", como o chamou Pedro II, e concentrar atenções no projecto do Marquês de Sá da Bandeira: o negro considera maus os portugueses porque o escravizaram e porque estendem esta prática aos seus próprios compatriotas; dos senhores brasileiros só diz bem.

No entanto, como em Hugo, aparecem também determinados paradoxos ideológicos, o que não tem, certamente, a ver com a leitura que Gomes de Amorim fez de Bng-Jargal, mas com a sua própria visão do problema, a que uma divisão maniqueísta romântica vem dar reforço. O negro, cativo submisso, é pintado como herói que conquista a alforria por suas qualidades ${ }^{12}$. Em Ódio de Raça, nem chega a aflorar aquela ideia transmitida por Habibrah, de que só em liberdade é possível mostrar o verdadeiro rosto. Até Emilia, o "Anjo dos Escravos", pensa que ela não é um direito, mas um prémio: por isso deu a alforria "só a seis" negros e simpatiza apenas com os que "merecem", pois "a escravidão não consegue torná-los maus" (Amorim, 2000: 71) e não vê nenhum problema em libertar os cativos, pois eles, "por gratidão" não deixam a fazenda. E se o texto não dá oportunidade de que ela se aperceba do amor de Cazuza, ao contrário do que acontece no romance de Hugo, o seu não à mistura racial é explícito: "- Mulher dum mulato? ... Antes morrer!" (Amorim, 
2000: 85). Dos escravos pensa que, mesmo educados, não podem vencer "os prejuízos de sua casta" (Amorim, 2000: 58).

Roberto, apesar de alegar que não trata mal os escravos, considera-os objectos necessários, valorizando-os como instrumentos ou animais que sustentam a sua riqueza, isto é, como bens de que é proprietário. E mesmo quando concorda que um escravo é bom, lamenta: "é pena que seja preto, porque tem alma de branco" (Amorim, 2000: 71). Quando vem a saber que é pai do mulato (facto que parece tentou obliterar, pois a negra Maria lhe falara nele), não se horroriza por ter escravizado o próprio filho; mostra-se arrependido, mas não pede perdão. Tão pouco o espectador fica chocado com a reacção de Roberto: as atitudes de Domingos, pintadas como o foram, já o tornaram perfeitamente abominável.

Mesmo sendo bom, o senhor que educou e alfabetizou Cazuza vendeu-o a Roberto. Manuel, bom rapaz, faz coro com a prima nos seus pedidos de liberdade para Cazuza, mas em nada contraria o sistema vigente (e nada há por parte de Gomes de Amorim, que se oponha a esta visão, o que mais uma vez parece apontar como problema principal a mistura de cores). Os brancos assumem, assim, diferentes graus de "bondade", mas não conseguem libertar-se de uma visão racista, que também atinge os negros, e de uma ideologia escravista.

Pode-se mesmo dizer, que apesar de sua intenção abolicionista, o texto mantém o racismo. Se Cazuza não chega a ser um Hércules negro como Bug, é esperto, trabalhador, humilde, alfabetizado e honrado, honra que em alguns momentos lhe será atribuída pelas virtudes que o catolicismo cultivou no seu espírito

Domingos, que o senhor "nunca açoitou" e goza de alguns privilégios, como Habibrah, procura fazer mal a seu dono, como o anão: rouba-o, deseja a sinhá branca, odeia os negros e insulta os portugueses recém-chegados. Seu ódio pelos brancos cresce ao saber que é filho do senhor. Associa-se, então, a outros mulatos igualmente bastardos para pôr em prática os seus planos. Os maus caracteres que lhe são atribuídos não se apagam, mesmo quando postas em relevo as causas da sua revolta e denunciados os males da escravidão (os senhores que usam as escravas, que tornam cativos os próprios filhos para aumentar o cabedal, que mandam açoitá-los, que os vendem a outros senhores $\left.{ }^{13}\right)$. Embora "desculpadas" por Cazuza, que, apesar de declarar que "mulato não tem

Este parece ser, para o autor, o pior problema do sistema, pois é dele que fala no

prólogo, juntamente com o da separação da família. 
raça" e desprezar os mestiços, vê nelas atitudes de quem é "'filho do opróbrio e da ignomínia", as acções de Domingos reforçam junto dos espectadores o ponto de vista do negro e da tapuia Marta, para quem "os mulatos não são bons" - o que não deixa de ser um eco das palavras de Denis - apesar de ela, como era de esperar, atribuir o facto a um "castigo de Deus" e não às causas "científicas" dos autores franceses (Amorim, 1869: 148).

O abolicionismo em Ódio de Raça situa-se principalmente no discurso do negro e do mulato, no qual Gomes de Amorim concentra o desenho, embora "a medo", "das abjecções e torpezas" da escravatura (Amorim, 1869: 15). O título da peça é, aliás, explicado dessa forma por Domingos:

[...] A minha raça é única e por isso aborreço as outras todas. Eu sou a escória o refugo dos homens, e sou escravo. Mas hei-de pagar-lhes em ódio e sangue tudo que lhes devo em desprezos. (Amorim, 1869: 32).

Marca-se dessa forma a ambivalência de um discurso que se pretende abolicionista: contra um "eles nasceram livres como nós", a alforria concedida só aos bons, o castigo para os maus, ainda que a humilhação esteja na raiz de suas atitudes de revolta. Afinal, o Outro é "quase igual, mas não completamente" (Bhabha, 1997: 153). Por isso, a liberdade total de Cazuza, que inclui o ser chamado pelo "nome de baptismo" por uma mulher branca, só encontra espaço no terreno da morte. Por isso, as misturas são rejeitadas e o canto de Bug-Jargal, que fala da necessidade de o dia unir-se à noite para produzir a aurora, permanece apenas como anúncio, enquanto Domingos continua exemplar de uma raça única e sem passado ${ }^{14}$.

\section{UMA HIPÓTESE DE AURORA}

Em 1856, Alencar proclamava, nas Cartas sobre $A$ Confederação dos Tamoios, a necessidade da criação de um poema épico nacional. A matéria da composição - o encontro de brancos e índios e suas consequências - delineado em Gonçalves Dias, poeta apreciado pelo escritor, e mal abordado por Gonçalves de Magalhães, objecto de suas críticas, parecia já ir ganhando contornos em seu pensamento: Alencar falava em "raça extinta" e reclamava de Dias um poema de maior

14 O mesmo se poderia dizer com relação a O Cedro Vermelho, onde o amor do

índio pela branca e desta por ele não tem curso.

Faculdade de Letras | Universidade de Coimbra 
fôlego, ao mesmo tempo que procurava uma "Eva indiana" de "faces cor de jambo" (Alencar, 1994a: 173 e 172) E se Chateaubriand era o nome que mais fortemente marcava o texto das Cartas, o elogio à capacidade de Victor Hugo em pintar dramaticamente as cenas indiciava a sua leitura.

Em 1857, as páginas do Diário do Rio de Janeiro estampavam aquele que se tornaria um dos mais populares romances brasileiros, e teria por centro o amor do índio pela moça branca: $O$ Guarani. Peri salvava Ceei por mais de uma vez: primeiramente, de uma pedra que iria esmagála; depois, saltando sobre um precipício, libertava a menina das mãos de um apaixonado de maus instintos; doutra vez, atirando em duas índias que iriam atacá-la durante o banho; finalmente, tirá-la-ia adormecida das chamas de um incêndio ateado pelos "revoltosos", agora aimorés que se vingavam da morte de uma índia. O pavilhão de descanso de Maria transformava-se numa latada de jasmineiros feita pelo índio para servir de casa de banho à moça branca. Uma antiga xácara portuguesa narrava, como a canção em espanhol, uma história em que um homem de outra raça perde por amor à mulher branca a sua religião e a sua liberdade.

Poder-se-ia dizer que qualquer semelhança com o Bug-Jargal é mera coincidência? Talvez. Peri é, como o negro haitiano, filho de rei. Os brancos não chegaram a enganá-lo como ao chefe Kakongo, nem a escravizá-lo, mas ele combateu-os, junto com os goitacás de sua nação, em Vitória. A sua excepcionalidade, mostrada também em várias ocasiões, adquire contornos semelhantes: de força, sagacidade, nobreza, domínio sobre os elementos da natureza. Peri não salva Cecília das mandíbulas de um jacaré, mas luta com uma onça; sua prenda não são malmequeres, mas a fera viva, para satisfazer um desejo de sua Senhora, um cabaz de palha com beija-flores, uma rola. Sabendo que a morte de Álvaro entristeceria Cecília e que ele a ama, salva-o de ser assassinado por Loredano.

A "voz argentina" de Cecília prende Peri (Alencar, 1994b: 125), como a de Maria faz palpitar o coração de Bug-Jargal. Este, por sua vez, declara em sua canção, que as formas de Maria, quando ela se banha no ribeiro, despertam-lhe emoção e afirma que, pela moça branca, esqueceria os seus e a sua terra. Semelhante declaração foi posta por Gonçalves Dias, na já referida "Canção do índio", na boca de um selvagem, que deixaria os seus, tornando-se escravo dos brancos, para "gozar" a loura "Virgem dos Cristãos formosa", que ele também contemplara no banho.

Alencar apropria-se da canção de Bug-Jargal e do "Canto do índio" e insere-os aos poucos no texto de $O$ Guarani: a imagem de Nossa 
Senhora, verdadeira virgem dos cristãos, que Peri vira no incêndio de uma igreja em Vitória, durante os combates ao lado dos goitacases, e que não lhe sai da cabeça, ele identifica com a de Ceei, de quem se torna vassalo e a cujo banho também assiste. A xácara acima referida vem a ser mais uma pista dessa reescrita do texto de Victor Hugo, agora mesclada ao de Gonçalves Dias.

Também Peri é humilde como Bug, e sabe que "tem a pele cor da terra" (Alencar, 1994b: 123), o que vem a ser motivo de desprezo e razão para não encontrar um lugar na "cidade dos brancos" (cf. Alencar, 1994b: 309). O ódio entre mestiços e os de sangue puro corre agora por outros canais, mas não deixa de existir: Isabel, mameluca, odeia Peri, que é índio, mas também os brancos, que a desprezam. Peri, por sua vez, com toda a sua dedicação e heroísmo, desperta a aversão de D. Lauriana e a antipatia de Aires Gomes. No entanto, esse filão não pode receber cores muito fortes: Alencar põe na boca do índio a esperança da mestiçagem. Depois de, numa espécie de mise-en-abyme, o selvagem narrar à moça branca a história de Tamandaré e sua mulher que, após um dilúvio, fundaram uma nova nação, Peri arranca uma palmeira e nela segue com Ceei, rumo ao futuro, rumo a aurora de uma nova raça, de uma nova nação. O seu "Tu viverás!” vem marcado por essa diferença em relação ao "Ele viverá!", proferido pelo Bug-Jargal. Afinal, Alencar pretendia contar a origem do povo brasileiro. Daí transformar a história de ódio de raças em história de amor, a história de escravos, em história de iguais na nação que estava por vir.

\section{DA ÓPERA DE GOMES AO MELODRAMA DE MALCHER}

Recriado na ópera de Carlos Gomes o romance de Alencar seria apresentado, em 1870, no Scala de Milão, percorrendo vários outros teatros italianos e da restante Europa, para chegar em Dezembro do mesmo ano ao Brasil, onde apareceria primeiramente no Teatro Lírico Fluminense (Rio de Janeiro). O enredo desse II Guarany seria basicamente o mesmo do de Alencar, mantendo-se quase todas as personagens. Também as citações de algumas cenas do Bug-Jargal permaneceriam, embora com propósitos e efeitos completamente diferentes e tão diluídas que se tornam quase irreconhecíveis, uma vez que já vêm mediadas pela obra de Alencar.

A apresentação de Peri, como a do escravo de António d'Auvernay, inclui de saída os dados de posição social e carácter: é filho 
de cacique e acaba de, heroicamente, salvar Cecília. Sua identidade obedece à mesma ambiguidade das obras anteriores, embora com menos ênfase: ele não precisa ser o "contrabandista" Pierrô/Bug-Jargal do romance de Hugo, pois não exerce os papeis de escravo e líder de revolta ao mesmo tempo; não é chamado por um nome "ridículo" e de escravo (Pai Cazuza) para libertar-se dele na morte, quando ouve o seu nome de baptismo - José; mas é um "cavalheiro português na pele de um selvagem" (Alencar, 1994b: 60) como o seu homónimo do romance de Alencar. E, se em Bug-Jargal o conhecimento da língua do dominador mostra a superioridade do negro (e também o seu "contrabando", pois ele move-se bem em vários territórios linguísticos); em Ódio de Raça, demarca o lugar de Pai Cazuza, que embora alfabetizado fala "língua de preto"; no romance de Alencar, identifica Peri, que fala na $3^{\text {a }}$ pessoa e usa a linguagem figurada; na ópera, talvez pela própria barreira do italiano em que foi escrita, não é utilizado como factor de discriminação: o Peri de Carlos Gomes expressa-se tão bem quanto as outras personagens.

A canção de Bug-Jargal, porém, com os seus dados de rei que, por amor, se torna escravo, apoiada pela saga narrada pelo Peri de Alencar, não traz mais à cena a visão da moça que se banha ou que tem bela voz, incitadas por Gonçalves Dias em seus versos, ou mesmo a sugestão da semelhança da virgem branca com a Virgem Maria. A paixão é mais súbita e até correspondida com mais rapidez. O problema da mestiçagem - mostrado como ódio no texto de Hugo e no de Amorim, e de que a Isabel, de Alencar, embora de boa índole, poderia ser uma testemunha - não é sequer aflorado. Aliás, esta Ceei não tem, como a de 1857, um receio inicial do índio. Pelo contrário, já no Io acto, ao saber-se prometida a Álvaro por D. António de Mariz, demonstra não gostar da ideia e fala em obediência à ordem paterna; a canção de amor que entoa, embora ela não tenha consciência disso, não se dirige a ele, mas a Peri. Este, por sua vez, sente "uma força indómita" que o impele para a moça branca, como ele próprio lhe explica. No $3^{\circ}$ acto, prisioneiros dos aimorés, diante da morte iminente, os dois declaram, abertamente, ao cacique inimigo o seu amor.

Todas essas cenas e a paixão de que é tomado o chefe aimoré ao ver a moça branca (cf. $3^{\circ}$ acto, cena II, cena e duetino), descartam por completo da ópera o ódio de raças presente no Bug-Jargal, assim como a mestiçagem e a ideia de fundação de uma nova nação de que o romance de Alencar é portador. Nem mesmo o incêndio, transposto para o final do texto, contribui para o heroísmo de Peri: ele fugiu, levando Ceei, antes que essa tragédia acontecesse. Nela morre D. António de Mariz e Ceei, 
assistindo tudo à distância, recebe o consolo do índio que lhe aponta o céu, a outra vida dos que crêem. O "Tu viverás" afirmado por Peri perde a sua razão de ser como prenúncio de continuidade numa raça a ser formada. Com isso, o nacionalismo de Carlos Gomes limita-se a, retomando um romance fundador da literatura brasileira, levar selvagens para o palco, e tentar ele próprio criar uma ópera brasileira, enquanto os episódios do texto de Hugo, usados em terceira mão, ganham, nesse novo transplante, a função de servir apenas ao dramatismo da cena e ao virtuosismo do bei canto.

Vinte anos depois do sucesso de II Guarany e exactamente dois anos depois da abolição da escravatura, um outro brasileiro, o paraense José Cândido Gama Malcher ${ }^{15}$, transporta para a ópera o próprio romance de Hugo, dando-lhe, inclusivamente, o mesmo título ${ }^{16}$. Um tal desfasamento entre o momento histórico e o tema eleito explica-se talvez pelo sucesso da transposição de outras obras do escritor francês para a cena, inclusivamente o Ernãni, que havia sido levado em Belém, nos anos de 1880, 1881, 1882, 1883, 1886 (cf. Páscoa, 2003: 46). No novo texto, porém, nota-se a interferência de Alencar ou de Carlos Gomes, que mantém em cena a índia "noiva do cárcere" cuja paixão liberta Peri das cordas que o prendem, enquanto este só tem olhos para a mulher branca: Malcher cria Irma, uma escrava negra que ama Bug e não é correspondida. E ela com o seu ciúme quem acaba por revelar a Leopoldo a identidade do cantor, o que termina por levar Bug à prisão, pois o noivo de Maria escarnece dele, que acaba por tentar apunhalá-lo. É também Irma que vai libertar Bug do cárcere onde se encontra por esse crime. Se esses antagonismos causados pelo amor sem correspondência não bastassem para transformar a ópera num texto de puro confronto de paixões, poder-se-ia acrescentar que a questão do ódio de raça e sua consequente ligação com a escravatura são praticamente apagadas. Os quadros terríveis da revolta (e mesmo os que têm a marca do preconceito) traçados por Hugo dão lugar a falas de Irma provocadas pelo ciúme contra Maria. A revolta dos negros parece não ter causa e serve como que

16 Outor foi recentemente objecto da tese de doutoramento de Páscoa (2003) que, no entanto, não teve acesso ao texto libreto publicado em Milão (cf Páscoa, 2003:101, n. 134).

16 Bug-Jargal, melodrama in qnattro atti, parole di Vicenzo Valle, musica del maestro J. C. Gama Malcher, Milano, Tipografia di Alessandro Gattinoni, 1890. O libreto, aliás, anuncia, logo de início, que "como rivela il tittolo" foi inspirado "dal romanzo BugJargal de Victor Hugo" (Valle, 1890a: 5). 
de pano de fundo. Eles cantam sua desdita, logo na abertura, falam do seu exílio, mas declaram que "I palpiti del cor/ gli son vietati" (Valle, 1890a: 6).

Em seu canto na ópera, Bug-Jargal deixa de lado a sugestão de mestiçagem contida nas imagens do crepúsculo e da aurora existentes na canção do escravo criado por Hugo, e apela simplesmente a Maria: "Uniamo i nostri cor." (Valle, 1890a: 16). A história de Bug que fala na perfídia do branco contra seu pai desaparece; apenas fica a ideia de que o negro foi rei em sua terra e, agora, é escravo. Por outro lado sem o contraste com as outras personagens de sangue negro (Habibrah, talvez pela dificuldade de colocar no palco um anão, não tem lugar na ópera, nem o seu relato de humilhações; o papel de Biassou, com seu despotismo, é reduzido; os maus sentimentos de Irma têm apenas relação com o seu ciúme) e sem o episódio do jacaré, a excepcionalidade de BugJargal fica bastante atenuada. Ainda mais que ele, além de agredir Leopoldo, nega-se a entregar Maria, depois de a haver salvo do incêndio: "Questa donna è mia! / Io solo dalle famine la salvai..." (Valle, 1890a: 29). (Entretanto , Leopoldo é preso por Biassou e a nobreza de Bug-Jargal brota de repente, menos por amor a Maria que por um problema de falta de domínio dramático de Vicenzo Valle: Jargal ordena ao mulato ${ }^{17}$ que liberte o branco). A língua italiana impõe ainda outra mudança: o "contrabandismo" de Jargal apaga-se e o domínio linguístico deixa de sublinhar a sua dupla condição de escravo e senhor, bem como a sua excepcionalidade. Em consequência desse enfraquecimento do ódio de raça e da excepcionalidade de Bug-Jargal, o problema da escravidão deixa de concentrar a atenção do espectador, que se fixa no conflito amoroso.

Gama Malcher, porém, procura seguir a trama de Hugo: Leopoldo é levado a Maria por Bug, que acaba por morrer pelas mãos dos aliados de d'Auvernay. Outro porém é o efeito da nova proporção e montagem dos ingredientes. A pergunta de Maria "Vincera fodio il amor?" e a frase final de Leopoldo — "Mi vinse amor!"- - (Valle, 1890a: 37 e 41) mostram que o maestro não possuía a mesma motivação do escritor francês: no Brasil de 1890, não havia porque falar de revolta de escravos ou de bandeiras vermelhas, tricolores ou com flor-de-lis; a recente república não tivera as mesmas proporções que o 1793. Por outro lado, os intelectuais ainda não estavam preocupados com uma nova identidade para o Brasil, como aconteceu durante o reinado de Pedro II.

\footnotetext{
${ }^{17}$ No libreto não há indicações sobre a cor desta personagem.
} 
$\mathrm{E}$, se na ópera foram incluídos instrumentos afro-brasileiros, como o curimbó18, $^{18}$ o gambá19, o caracaxá (grafado na versão italiana caracascia $^{20}$, a siririca ${ }^{21}$, eles talvez tenham servido apenas para conferir uma certa, mas deslocada 22 " "identidade étnica": o negro ainda não havia conquistado o direito de ser tratado como origem de uma raça nem identificado o seu contributo para a formação da cultura nacional.

\section{AURORA E CREPÚSCULO DE UM TEXTO}

O Bug-Jargal de Victor Hugo durante mais de quarenta anos foi recebido de forma produtiva no Brasil e em Portugal. Cenas, como a do incêndio e as das flores; espaços, como o pavilhão; expressões, como "viverás!"; ideias, como o ódio entre raças, a mestiçagem e a fronteira linguística e religiosa, encontraram um espaço histórico-cultural propício. Num contexto em que era preciso resgatar a imagem do índio, Bug-Jargal muda de pele, diz sim ao espírito de cruzada europeu e até antevê, numa outra vida, a hipótese de a noite unir-se ao dia formando a aurora ou o crepúsculo. Num momento em que está em jogo uma lei para abolir a escravatura em Portugal, ele aparece numa fazenda brasileira, negro e humilde, cristão e alfabetizado, eliminando as fronteiras possíveis e inspirando a piedade do espectador, enquanto o sucessor de Biassou e de Habibrah dá conta de outras monstruosidades do sistema escravagista. Nesses novos textos escritos dos dois lados do Atlântico, o incêndio

18 Segundo Câmara Cascudo (1962: 184 e 657), regista este tambor ou atabaque, como carimbo e anota sua utilização em dança de negros, homónima, realizada nos arredores de Belém do Pará e Marajó, acrescentando que a formação é a mesma da marujada de Bragança (Pará) ou retumbão, conhecida noutras regiões paraenses por carimbo ou corimbo.

19 Outro instrumento de percussão utilizado pelo caboclo paraense (cf. Cascudo, $1962: 340)$

${ }^{20}$ Espécie de reco-reco e o mesmo que ganzá, este instrumento teve também existência entre os índios do Brasil (cf. Cascudo, 1962: 341-342)

21 Cascudo não regista esta forma, mas siriri ou ciriri, e, assim mesmo, como dança, para a qual apresenta duas modalidades, nenhuma delas, porém mencionada como existente no Pará.

22 E de lembrar que a ópera passa-se em São Domingos e que, curiosamente, a chica, explorada por Victor Hugo também surge na ópera, evidenciando a intenção de Malcher em marcar etnicamente o texto.

Faculdade de Letras Universidade de Coimbra 
reforça uma vez mais o heroísmo da personagem e o "viverás" muda de destinatário, lembrando que, à custa do sacrifício do negro ou do índio, o branco, ainda que em mistura, continuará senhor, impondo língua e religião.

A transposição do romance de Hugo para a ópera, que apresentaria dificuldades semelhantes às da mudança para os códigos dramáticos, parece diminuir em muito a sua vitalidade, pelo próprio facto de serem textos epigonais. Sintomaticamente, desaparece o "viverás" e a canção de Bug perde o sentido da construção nacional. Resta apenas o incêndio, pela sua grande dramaticidade, aquela mesma que Alencar já louvara no escritor francês, por ser mais um obstáculo ao amor (que tanto Carlos Gomes como José Cândido da Gama Malcher se mostram interessados em reforçar, com a formação de novos triângulos ${ }^{22}$ ) revelando nele, nele sim, o filão sobrevivente, ainda que a recusa à diferença, vivida por Gonçalves Dias, continuasse a existir na cena social brasileira.

\section{BIBLIOGRAFIA}

- Alegre, Caetano da Costa (1994) Versos, Lisboa, Imprensa NacionalCasa da Moeda.

- Alencar, José de (1994a) Iracema, Coimbra, Livraria Almedina.

- Alencar, José de (1994b) O Guarani, Coimbra, Livraria Almedina.

- Amorim, Francisco Gomes de (2000) Ódio de Raça. O Cedro Vermelho. Braga, Angelus Novus (edição de Maria Aparecida Ribeiro e Fernando Matos Oliveira).

- Amorim, Francisco Gomes de [1982] Os Selvagens, Lisboa, Promoclube.

- Bhabha, Homi (1997) "Of Mimicry and Man: The Ambivalence of Colonial Discourse", Tensions of Empire. Colonial Cultures in a Bourgeois World, Frederick Cooper and Ann Laura Stolar (eds.), Berkeley/Los Angeles/London, University of California Press, p. 152162.

- Cascudo, Luís da Câmara (1962) Dicionário do Folclore Brasileiro, Rio de Janeiro, Instituto Nacional do Livro.

- Cauna, Jacques de (1985).'Les sources historiques de Burg-Jargal: Hugo et la révolution haitienne", Conjontion, $\mathrm{n}^{\circ} 166$.

\footnotetext{
J Ceci-cacique Aimoré-Peri; Irma-Bug- Maria.
} 
- Debien, G. (1952) “Un roman colonial de Victor Hugo: Bug-Jargal. Ses sources et ses intentions historiques", Revue d'Histoire Littéraire de la France, 1952, v. 52, p. 298-313.

- Dias, Gonçalves (1959) Poesia Completa e Prosa Escolhida, Rio de Janeiro, Editora José Aguilar.

- Gomes, A. Carlos (1938) O Guarani, Rio de Janeiro, Imprensa Nacional (versão brasileira e adaptação musical de C. Paula Barros, segundo o original italiano de Antonio Scalvini).

- Grimm, Gunter (1977) Rezeptionsgeschichte: Grundlegung einer Theorie: mit Analysen und Bibliographie, München , W. Fink.

- Hoffmann, Léon-François (1989) "L'Idéologie de Burg-Jargal", http.// grouugo.div.jussieu.fr/ Groupugo / 1989-05-25 Hofmann.htm.

- Hoffmann, Léon François (1973) Le Nègre romantique, personage littéraire et ohssession collectif, $\backslash$ Paris, Payot.

- Hugo, Victor (s.d.) Bug-.Jargal, Obras Completas, Porto, Lei lo \& Irmão, v. I, p. 323-446).

- Laforgue, Pierre (1989) “Bug-Jargal ou de la dificulté d'écrire en 'style blanc"”, http.// grouugo.div.jussieu.fr / Groupugo /

1989-06-17

Laforgue., htm.

- Macedo, Joaquim M. de \& outros (1851) "Parecer da Comissão de História sobre o Opúsculo: 'Une Fête Brésilienne...'”, Revista do IHGB, t. XIV, RJ, 443-449.

- Páscoa, Márcio Leonel Reis (2003) A Ópera na Amazónia no Tempo da Borracha (1880-1907): Bug-Jargal de José Cândido da Gama Malcher, Coimbra, Universidade de Coimbra (tese de doutoramento policopiada).

- Ribeiro, Maria Aparecida (1998) "Gente de todas as cores: imagens do Brasil na obra de Gomes de Amorim”, Máthesis, Viseu, v.7, p.1 17-164.

- Ribeiro, Maria Aparecida (1999) «Imagens do Brasil na obra de Garrett: invocações e exorcismos», Camões, Revista de Letras e Culturas Lus áfonas, 4, Jan-Mar, p. 1 15-127.

- Sayers, Raymond S. (1956) O Negro na Literatura Brasileira, Rio de Janeiro, Edições O Cruzeiro.

- Toumson, Roger (1979) Bug-Jargal ou la révolution haitiene vue par Victor Hugo. Les deux versions du roman présentées et anotées par..., Fort-de-France, Désormeaux.

- Valle, Vicenzo e Malcher, J.C. Gama (1890a), Bug-Jargal, melodramma in quattro atti, Milano, Tipografía di Alessandro Gattinoni.

- Valle, Vicenzo e Malcher, J.C. Gama( 1890b), Bug-Jargal, melodrama em quatro actos, Pará, Typografia d"“O Democrata”. 